\title{
MUDANÇAS DE ORGANIZAÇÃO DO TRABALHO, VULNERABILIDADE SOCIAL E RECOMPOSIÇÃO DE CLASSES NO CAPITALISMO CONTEMPORÂNEO
}

\author{
CHANGES IN WORK ORGANIZATION, SOCIAL VULNERABILITY \\ AND RECOMPOSITION OF CLASSES IN CONTEMPORARY CAPITALISM
}

Ediano Dionisio do Prado ${ }^{1}$

\section{RESUMO}

O presente texto, de natureza descritiva, tem por objetivo apresentar uma abordagem panorâmica de discussões fulcrais das ciências sociais, especificamente da Sociologia, a respeito do capitalismo contemporâneo: a) as metamorfoses da organização produtiva; b) a questão da vulnerabilidade das camadas trabalhadoras e c) a reconfiguração das classes sociais. As demandas de disciplinamento da mão de obra para a produção, a interconexão produtiva global e as configurações sociais, políticas e culturais, atinentes às dinâmicas do fordismo e do toyotismo, foram tomadas como instrumento metodológico para a compreensão dos impasses e inquietações presentes na contemporaneidade. No âmbito do trabalho, essas modificações produzem uma profunda vulnerabilidade, com diminuição dos salários, terceirização, desemprego e elevação do número de pessoas desfiliadas do processo produtivo. Na esfera das relações entre grupos e segmentos sociais, emergem discussões sobre uma nova conformação de classes.

Palavras-chave: fordismo, sociologia, teoria de classes, toyotismo, vulnerabilidade social.

\begin{abstract}
The present text, of a descriptive nature, aims at a panoramic approach of central discussions of the social sciences, specifically of Sociology, regarding contemporary capitalism: a) the metamorphoses of the productive organization; $b$ ) the question of the vulnerability of the working layers, and; c) the reconfiguration of social classes. The demands of disciplining the labor force for production, the global productive interconnection and the social, political and cultural configurations, related to the dynamics of Fordism and Toyotism, were taken as a methodological tool for understanding the impasses and concerns present in the contemporaneity. In the field of work, these changes produce a profound vulnerability, with wage degradation, outsourcing, unemployment and an increase in the number of people disillusioned in the production process. In the sphere of relations between groups and social segments, discussions about a new class conformation emerge.
\end{abstract}

Keywords: fordism, sociology, class theory, toyotism, social vulnerability.

\section{INTRODUÇÃO}

No século XIX, a sociedade capitalista industrial, em consolidação e expansão, introduziu outras formas de organizar a vida, favoreceu o fortalecimento de novos atores sociais e o surgimento de novas problemáticas. A industrialização e urbanização acentuadas

1 Docente EBTT no IFSULDEMINAS (Instituto Federal do Sul de Minas), Campus Inconfidentes. Mestre em Sociologia (Unicamp) e doutorando em Ciências Sociais (IFCH \Unicamp). 
promoveram amplos efeitos interrelacionados, como o êxodo rural, a miserabilidade, o alcoolismo, o aumento do suicídio ${ }^{2}$, do infanticídio, da criminalidade, dos surtos de epidemia etc. O processo de industrialização foi caracterizado pelos conflitos entre os novos grupos: os proprietários capitalistas (concentradores dos meios de produção) e os operários modernos que vendem sua força de trabalho por um salário, experimentando a miséria, péssimas condições laborais, de moradia e de vida ${ }^{3}$.

As novas e profundas realidades geraram uma atmosfera de aturdimento psíquico, de agitação e turbulência, tornando-se premente a necessidade de alçar a sociedade à condição de objeto de análise. Nessa perspectiva, a Sociologia teve seu nascimento visceralmente atrelado à solidificação da sociedade industrial, bem como a seus problemas, suas crises e seus antagonismos. No decorrer do século XX, o sistema produtivo aprimorou seus mecanismos e suas estratégias de disciplinamento e formatação da mão de obra, transpondo os muros das fábricas e configurando aquilo que Weber $(1999 ; 1979)$ apontou como a característica da sociedade moderna: a racionalização, entendida esta no âmbito da dominação de massa e na esfera da organização da força de trabalho e gerenciamento da produção. Ocorreu a sedimentação de um modelo de gestão do trabalho, o fordismo/toyotismo, consorciado a um padrão de sistematização das relações de consumo, atrelado a uma ordenação política de seguridade social (com intervenção regulatória do Estado) e orientado pela centralidade do trabalho como produtor de valor.

Nas décadas finais do século XX, novas problemáticas se desenharam nitidamente nos horizontes da sociedade contemporânea, inquietando a intelectualidade e envolvendo mulheres e homens em um sentimento de incertezas e questionamentos. Esse novo cenário, segundo Offe (1989), descortinou amplos horizontes e desafios para a Sociologia ${ }^{4}$, colocando em discussão os modelos teóricos construídos na explicação da sociedade capitalista industrial. Se a sociedade industrial pôde ser comumente explicada pela polarização entre as classes burguesa e proletária, por meio da importância do trabalho humano na produção de valor, nas últimas décadas o discurso hegemônico, no seio das organizações empresariais e no staff de organismos internacionais (como o FMI - Fundo Monetário Internacional) e de aparelhos nacionais estatais ${ }^{5}$, tem sido a negação da contradição, da dialética e do movimento entre capital e trabalho. Na interpretação unilateral dos apologistas do capitalismo, a derrocada do socialismo de estado (esboroamento do sistema soviético) significou a consolidação de uma nova ordem mundial, caracterizada por globalização, abertura dos mercados, falência do Estado-interventor, reestruturação das

\footnotetext{
2 A morbidez da rápida transformação social do século XIX apresentou, no parecer de Durkheim ([1897] 2000), um tipo predominante de suicídio: o anômico. As incertezas e instabilidades da modernidade alavancaram correntes suicidógenas pautadas principalmente no esboroamento dos costumes que até então ordenavam a vida social e na insuficiente consolidação de novos valores ordenadores (anomia).

3 Lefebvre pontua que "a industrialização fornece o ponto de partida da reflexão sobre nossa época" (1991, p. 3). Em sua análise, a urbanização seria efeito induzido, e não elemento indutor da industrialização.

4 A tarefa que os pensadores positivistas se propuseram foi a de racionalizar a nova ordem, encontrando soluções para o estado de "desorganização" então existente. Mas para restabelecer a "ordem e a paz" seria necessário conhecer as leis que regem os fatos sociais, instituindo, portanto, uma ciência da sociedade. Ao contrário do positivismo, que procurou elaborar uma ciência social reputada "neutra", Marx e Engels (1998) e vários de seus seguidores deixaram clara a íntima relação entre o conhecimento por eles produzido e os interesses da classe, por eles, conceituada revolucionária, existente na sociedade capitalista - o proletariado. O pensamento marxista tomou as contradições do capitalismo como um dos seus focos centrais.

5 Esse discurso é encontrado no seio das escolas de economia e administração e no âmago do aparato de ministérios das áreas do trabalho, economia e planejamento, responsáveis pela produção e reprodução da lógica da eficiência/eficácia na gestão. "O discurso hegemônico no meio empresarial tem como tema central a busca por competitividade” (DRUCK, 1999, p. 129).
} 
empresas, flexibilização do trabalho e inovações tecnológicas. Tal estado de coisas configuraria uma nova etapa do capitalismo, denominada por Masi (2000) como "sociedade pós-industrial"6.

Nesse contexto, a Sociologia, umbilicalmente presa à análise da sociedade, produziu vasta literatura. Em grande parte dessa bibliografia, a compreensão das transformações presentes perpassa a constatação de que as problemáticas atuais foram gestadas no ventre da sociedade salarial e são elucidáveis mediante processos tais como: avanço tecnológico, reestruturação da base produtiva, globalização da economia e do mercado de trabalho. Devem-se compreender os elementos dinâmicos do capitalismo industrial que originaram a reestruturação produtiva, o desemprego estrutural ${ }^{7}$ e a precarização, de um lado, e o desmonte do aparato estatal intervencionista e ofertante de serviços coletivos, de outro.

Com o propósito de desenvolver alguns aspectos das transformações processadas, adotamos, como estratégia metodológica, a exploração de três pontos cruciais: I) as mudanças na organização produtiva expressas na transição do fordismo/taylorismo ao toyotismo; II) a vulnerabilidade crescente das camadas laborais com o desemprego estrutural, a precarização das relações trabalhistas e os ataques assertivos às leis previdenciárias e de proteção trabalhista em nome do saneamento das receitas estatais; III) a reconfiguração das classes sociais, levandose em consideração a transformação do conhecimento científico em fator de produção. $\mathrm{O}$ presente artigo, longe de pretender inovações conceituais ou análise fundamentada em pesquisa empírica e pontual, objetiva uma abordagem panorâmica da temática.

\section{METODOLOGIA}

A seleção da bibliografia utilizada na edificação do corrente texto baseou-se na pertinência das obras no campo da Sociologia e sua relevância para a compreensão e consecução dos objetivos propostos. O presente artigo delineia aspectos relevantes da discussão de modelos de organização do trabalho, da questão da vulnerabilidade social das classes trabalhadoras e da reconfiguração de classes sociais no capitalismo contemporâneo, conformando leitura plausível no universo das ciências sociais, das organizações e na esfera de inúmeros cursos universitários.

\section{VISÕES CONTRAPOSTAS: OTIMISTAS VERSUS CÉTICOS}

A partir da Revolução Industrial no século XIX, o desenvolvimento da sociedade capitalista pode ser resumido pela extraordinária aventura da condição do capitalista e do assalariado. Ocorreu a cristalização do trabalho como eixo das relações sociais. As transações de

\footnotetext{
6 Masi (2000) prefere o termo sociedade "pós-industrial” devido ao sucesso de que essa denominação já desfruta desde finais dos anos 1960, conformando títulos de obras e pontuando discussões. Contudo, algumas cautelas devem ser adotadas para que essa denominação não seja entendida de modo equívoco, como algo totalmente melhor do que a sociedade industrial, um estágio no qual se nega o próprio caráter histórico do sistema capitalista. Nas colocações de Sader: "Até a palavra capitalismo tendeu a desaparecer, como forma mais acabada de sua naturalização. Se nos anos 60 se discutia quando e como o capitalismo desapareceria, nos 90, discute-se - não se o capitalismo tem futuro, mas - o futuro do capitalismo" (1997, p. 12).

7 O desemprego estrutural faz parte da dinâmica do processo de reestruturação produtiva, tende a se tornar permanente. Contrariamente, o desemprego conjuntural é suscitado por um momento adverso para um setor produtivo ou para a economia em geral. Uma vez superada a adversidade, a tendência é a retomada dos níveis e indicadores anteriores de empregabilidade, o que não ocorre na realidade do desemprego estrutural.
} 
compra e venda do trabalho ${ }^{8}$ puderam ser vistas como um processo que originou configurações culturais, simbólicas e de identidades pessoais.

O modo de vida capitalista industrial envolveu muito mais do que orientações organizadoras dos processos de trabalho e acumulação de capital. Harvey (2003) assinala que o capitalismo plasmou modos de consumo e estilos de vida com ampla penetração na identidade do indivíduo: todo um complexo de forças implicadas na proliferação da produção, da propriedade e do uso em massa de mercadorias símbolos, como o automóvel ${ }^{9}$.

Em torno do trabalho construiu-se, também, todo um aparato de proteções e seguridade, toda uma estrutura de socialização individual. Edificou-se uma legislação (por exemplo, a Consolidação das Leis Trabalhistas - CLT, de 1943, no Brasil), que acenava segurança e solidariedade aos inseridos nas relações contratuais, mediante o Estado Social ou Estado Previdência. As relações de trabalho foram, na constatação de Castel (1998), definidas em um quadro contratual, por meio da mobilização dos trabalhadores, da atuação dos sindicatos e da intervenção estatal.

Hodiernamente, um acelerado processo de desvalorização do trabalho suscitou a discussão sobre a centralidade deste como produtor de valor. De maneira generalizada, principalmente nos países centrais do capitalismo, os índices de desemprego alcançaram números recordes. Muitos estudiosos classificam tal processo como a era do desemprego estrutural. $\mathrm{Na}$ interpretação de Offe, inúmeros obstáculos na esfera produtiva se colocam à possibilidade de incrementar a criação de postos de trabalho formalizado, descaindo a centralidade da atividade laboral:

[...] os processos multidimensionais de diferenciação (convincentemente comprovados em diversos estudos sobre a segmentação do mercado de trabalho e a polarização das qualificações), e as mudanças econômicas, organizacionais e técnicas das condições de trabalho, que se apresentam com o correr do tempo, parecem indicar que a qualidade de "trabalhador" dificilmente ainda pode ser tomada como o ponto de partida para a formulação de agregados culturais, organizacionais e políticos, e para interpretações coletivas. (1989, p. 20-21)

Antunes, discorrendo sobre as transformações no mundo do trabalho, descortina uma múltipla processualidade. Segundo o autor, pode-se constatar, paradoxalmente, um efetivo processo de intelectualização do trabalho manual, ao lado de uma desqualificação e mesmo subproletarização:

[...] uma desproletarização do trabalho industrial, fabril, manual (redução do número de operários tradicionais). De outro lado, paralelamente, efetivou-se uma expressiva terceirização do trabalho, concretizando uma subproletarização, trabalho precário, informal, temporário. Ocorre, também, uma ampliação do assalariamento no setor de serviços. (apud ANTUNES, 1997, p. 73)

\footnotetext{
8 O operário, na perspectiva marxista, é aquele indivíduo que, nada possuindo, é obrigado a sobreviver da venda de sua força de trabalho. Esta corresponde ao conjunto das faculdades físicas e espirituais que existem na corporalidade, na personalidade viva de um homem e que ele põe em movimento toda vez que produz valores de uso de qualquer espécie. No capitalismo industrial, a força de trabalho se torna uma mercadoria, algo útil, que se pode comprar e vender. A força de trabalho, como mercadoria, apresenta a peculiaridade de acrescentar valor a outras mercadorias, de transformá-las. Para Marx (1996), o trabalho, ao se exercer sobre determinados objetos, provoca nestes uma espécie de "ressurreição". Tudo o que é criado pelo homem, diz o autor, contém em si um trabalho passado, "morto", que só pode ser reanimado por outro trabalho. Incorpora-se um novo valor. Surge assim um contrato entre capitalista e operário, mediante o qual o primeiro compra ou "aluga por um tempo" a força de trabalho e, em troca, paga ao operário uma quantia em dinheiro, o salário.

9 Em sua análise, Harvey (2003) destaca que, no capitalismo, o consumo e certo padrão de eficiência produtiva assumem vasta gama de significados sociais, psicológicos, políticos, bem como mais propriamente econômicos. Certas propensões sociais e psicológicas incentivam a busca da realização pessoal e a individualidade.
} 
Abalizados teóricos da Sociologia indicam a exigência de um redimensionamento conceitual para a compreensão da nova etapa do capitalismo, tendência que vem se desenvolvendo desde o final da Segunda Guerra Mundial e que, a partir de 1970, ganhou contornos mais nítidos. Não almejamos, dadas as limitações deste artigo, proceder a uma redefinição conceitual; meramente pretendemos apontar alguns elementos sociológicos na transição do fordismo para o toyotismo que possibilitem descortinar nuances da dinâmica suprarreferida, tornando o olhar mais suscetível e sensível às novas perspectivas, às mudanças na configuração das classes sociais e no estado de vulnerabilidade dos segmentos trabalhadores.

Deparamo-nos com uma realidade que provoca uma inquietação muito grande em mulheres e homens, uma sensação de crise. Frente a esse quadro, duas posições sobressaem: otimistas e pessimistas. Os otimistas, ou apologistas, referendam a tese hegemônica neoliberal; constroem um diagnóstico extremamente positivo, tomando o progresso tecnológico como inevitável e proveitoso. Segundo Masi (2000), os otimistas advogam que a sociedade caminha para o bem-estar, em função do progresso, da riqueza, da urbanização, do emprego prático da ciência e da tecnologia. Já Araújo afirma o seguinte:

A posição neoliberal vê a emergência do mercado global e a competitividade global como elementos impulsionadores do progresso e festejam o triunfo das forças impessoais do mercado sobre o poder estatal. Sua visão otimista os leva a ressaltar os benefícios em termos de maior eficiência e bem-estar que a emergência de uma economia global propaga pelo mundo. (ARAÚJO, 2001, p. 8)

Os pessimistas, os céticos e os críticos, ao contrário, no parecer do autor italiano Domenico de Masi (2000), lançam um olhar desabonador. Desenvolvem uma crítica rigorosa que contribui para decompor e desmistificar os conceitos de progresso e de globalização. Recusam o produto interno bruto, a industrialização, o gigantismo na economia, a tecnocracia e o consumismo como parâmetros do bem-estar. A atenção se volta para a questão das maiorias (grupos excluídos, países do terceiro mundo etc.) ${ }^{10}$. Para eles, a tecnologia pode produzir danos gravíssimos, uma vez que os homens estariam pautados pela cisão entre o conhecimento técnico e o humanista. Considerando que a razão instrumental predomina sobre a crítica, o progresso técnico favorece uma pequena minoria, pois não ocorre uma distribuição equitativa da riqueza produzida.

\section{DISCIPLINAMENTO DO TRABALHADOR: A FORÇA OBJETIVANTE CONTRA A VONTADE SUBJETIVA}

A compreensão dos efeitos do processo de reestruturação produtiva, das novas tecnologias e da racionalização na esfera do trabalho reclama a retomada dos modelos de organização do trabalho ao longo do século XX: o fordismo e o toyotismo, as principais configurações de disciplinamento do corpo e da vontade do operário.

Silva pontua que "a transformação do trabalhador em força de trabalho verifica-se a partir da produção de mecanismos de dominação e controle por parte do capital e de sua

\footnotetext{
${ }^{10}$ Araújo (2001) coligiu e classificou os livros e artigos sobre o tema da globalização, elucidando que as diferenças na definição do fenômeno implicam modos distintos de identificação de suas conseqüências e relações para o trabalho. Quanto aos otimistas neoliberais, foram esses mesmos paladinos da desregulamentação que, frente os prejuízos da crise alastrada a partir de 2008, abandonaram com agilidade e rapidez suas convicções e cobraram, dos governos, incentivos, subsídios, empréstimos e políticas para minorar suas perdas. Abandonaram o brado altissonante da flexibilização, da liberalização dos mercados, em prol do argumento das responsabilidades do Estado na economia.
} 
interiorização por parte dos trabalhadores" (1999, p. 105). Por meio do controle da capacidade produtiva em mulheres e homens, o capital garante sua reprodução; apropria-se do fruto do trabalho do operário.

Contudo, o processo de disciplinação da força de trabalho para os propósitos de acumulação de capital é extremamente complexo. Ele envolve alguma mistura de repressão, familiarização, cooptação, cooperação e resistência (organizada e manifesta, além da cotidiana e silenciosa). Não existe aí uma relação mecânica. Em palavras de Silva:

Não existe aí uma relação mecânica. Ao contrário, trata-se de um processo que envolve posições, resistências, construções e desconstruções, contradições das organizações sociais de classe, gênero e étnico-racial. Portanto, não existe um único sistema de dominação fabricado pelo capital e operante apenas durante o ato produtivo. (1999, p. 105)

Os elementos de disciplinação têm de ser organizados não somente no local de trabalho, mas na sociedade como um todo. No seio da sociedade, pontuam Harvey (2003) e Dawsey (1990), inúmeras forças reforçam essa familiarização ao trabalho, reproduzindo ideologias dominantes por meio da mobilização de certos sentimentos sociais (a ética do trabalho, a lealdade aos companheiros, o orgulho nacional) e de propensões psicológicas (a busca de identidade pelo trabalho, a iniciativa individual ou a solidariedade social).

Nas palavras de Harvey, "todo tipo de trabalho exige concentração, autodisciplina, familiarização com diferentes instrumentos de produção e o conhecimento das potencialidades de várias matérias-primas em termos de transformação em produtos úteis" (2003, p. 119). As regras capitalistas de produção "representam uma verdadeira ética corretiva para o trabalho, um remédio eficiente para extirpar hábitos, valores prevalecentes nos sistemas de trabalho anterior, empobrecendo assim o mundo interior" (SILVA, 1999, p. 18).

O processo de disciplinamento do trabalhador, pelo capital, significa dominá-lo, por um ato de força objetivante contra a vontade subjetiva. A introjeção da exploração e da dominação é constitutiva da experiência do trabalhador. A familiarização dos assalariados foi um processo histórico bem prolongado que tem de ser renovado com a incorporação de cada nova geração de trabalhadores à força de trabalho ${ }^{11}$.

\section{FORDISMO: MODO DE ORGANIZAÇÃO DO PROCESSO DE TRABALHO E DE RELAÇÕES SOCIAIS}

O final do século XIX e o início do XX caracterizaram-se, nos países ricos, pela concentração da riqueza e do poder político nas mãos das gigantescas corporações (monopólios industriais, comerciais e financeiros). Essas corporações, além dos mercados nacionais,

\footnotetext{
11 Boltanski e Chiapello trabalham com o conceito de "espírito do capitalismo": "O espírito do capitalismo é justamente o conjunto de crenças associadas à ordem capitalista que contribuem para justificar e sustentar essa ordem, legitimando os modos de ação e as disposições coerentes com ela. Essas justificações, sejam elas gerais ou práticas, locais ou globais, expressas em termos de virtude ou em termos de justiça, dão respaldo ao cumprimento de tarefas mais ou menos penosas e, de modo mais geral, à adesão a um estilo de vida, em sentido favorável à ordem capitalista” (2009, p. 42).
} 
expandiram seus interesses às áreas sob o jugo imperialista ${ }^{12}$. Internamente, como acusam Hunt e Sherman (1988), os trabalhadores alcançaram, gradativamente, conquistas importantes em termos de legislação trabalhista, com regulamentação da dimensão da jornada de trabalho, trabalho infantil e trabalho feminino. Em alguns países, os trabalhadores vivenciaram a elevação dos salários reais.

Nesse contexto, objetivando um processo ininterrupto de produção coletiva em massa, geração de lucro e acúmulo de capital, o modo de produção capitalista desempenhou um papel fundamental na racionalização da produção. Era preciso favorecer o aumento da produtividade do trabalho economizando tempo, suprimindo gestos desnecessários e comportamentos supérfluos no interior do sistema produtivo. Esse processo de racionalização da produção ganhou notoriedade na linha automática de montagem de automóveis de Henry Ford.

Em 1911, Frederick Winslow Taylor (1856-1915) - engenheiro americano - publicou os Princípios da administração científica ${ }^{13}$, incrementando a racionalização do processo de trabalho fordista, por isso o sistema é denominado de fordismo/taylorismo. Taylor aperfeiçoou a divisão social introduzida pelo sistema de fábrica, assegurando definitivamente o controle do tempo do trabalhador. O objetivo foi atingir o mais alto grau de eficiência e sedimentar um racional meio de exercer dominação sobre os seres humanos. Precisão, estabilidade, rigor disciplinar, padronização, sincronização, concentração, maximização e eficácia produtiva se tornaram alicerces de um grau particularmente elevado de calculabilidade dos resultados. Seu desenvolvimento, sob os auspícios do capitalismo, criou a necessidade de uma administração estável, rigorosa e intensiva.

Enquanto método de racionalizar a produção, o fordismo/taylorismo implicou a domesticação e a dominação do trabalhador. Processou-se a familiarização do trabalhador com longas horas de trabalho puramente rotinizado. O trabalhador-modelo, ideal, é o operário de tipo bovino, forte e docilizado: conduzido pelo ritmo da máquina, fustigado pelo comando dos gerentes e cooptado pelo incentivo salarial ${ }^{14}$, ou seja, um operário que desempenha funções repetitivas, em um ritmo acelerado - o operário que aperta parafusos.

A administração científica postula que para cada elemento do trabalho individual existe uma ciência que substitua os métodos empíricos. A forma racional de executar-se determinada operação, cada movimento, deve ser estipulada pela gerência. $\mathrm{O}$ trabalhador recebe as instruções de como e em quanto tempo deve realizar sua tarefa pormenorizada. Retira, portanto, do operário o controle sobre o projeto, o ritmo e a organização do processo produtivo. Objetivase o aprimoramento da divisão de trabalho no interior da fábrica: a separação entre as fases de planejamento, concepção e direção, de um lado, das tarefas de execução, de outro. Toda atividade de concepção, planejamento e decisão deve realizar-se fora da fábrica pela gerência

\footnotetext{
12 No olhar de Hunt e Sherman "os grandes empresários desta época não eram homens de muito escrúpulo. [...] Para eliminar seus concorrentes, não hesitavam em contratar assassinos profissionais, recorrer a sequestros e utilizar dinamite. Tampouco hesitavam em lesar o público em milhões de dólares através de manobras e operações fraudulentas na bolsa" (1988, p. 125). Passada a fase de concorrência, as empresas vitoriosas se organizam em trustes, cartéis e corporações conquistando prodigiosos lucros com a monopolização do mercado.

13 Taylor acreditava que o processo de produção das fábricas não podia ser deixado nas mãos dos próprios trabalhadores, que procuravam sempre retardar o ritmo de trabalho. Por isso, era necessário descobrir um método "científico" de direção das indústrias: como dirigir com o máximo de eficácia, obtendo o melhor rendimento, evitando qualquer perda de tempo na produção? A organização científica da produção, na crença de Taylor, iria beneficiar a empresa (com maior produtividade) e os trabalhadores (com maiores salários) (RAGO; MOREIRA, 1993).

14 Para Taylor, o homem-boi não era tão raro na humanidade nem tão difícil de encontrar que fosse demasiado caro. Pelo contrário, seria um homem tão imbecil que não se prestava à maioria dos tipos de trabalho. Chaplin, de forma magistral, constrói uma sátira desse modo de organização do trabalho no filme Tempos modernos.
} 
científica $^{15}$ e ser executada passivamente pelos trabalhadores. Sedimenta-se a hierarquia despótica da fábrica, com toda uma série de mecanismos coercitivos, como os analistas de tempo e de movimentos e a individualização dos salários ${ }^{16}$.

O fordismoltaylorismo acabou por penetrar e determinar até mesmo atividades que se realizam fora dos muros das fábricas. Modificou os processos de produção, conformou uma configuração cultural e psicológica sobre o trabalho, gerando uma nova estética e um novo padrão de consumo. Como salientamos anteriormente, forças e instituições sociais são mobilizadas para formatar o trabalhador fordista/taylorista. Assim, questões de sexualidade, de família, de formas de coerção moral, de consumismo e de ação do Estado estiveram vinculadas ao esforço de forjar um tipo particular de trabalhador e um novo tipo de homem.

Harvey assevera que no fordismo se processou o reconhecimento explícito de que a produção de massa significava consumo de massa:

O propósito do dia de oito horas e de cinco dólares só em parte era obrigar o trabalhador a adquirir a disciplina necessária à operação do sistema de linha de montagem de alta produtividade. Era também dar aos trabalhadores renda e lazer suficientes para que consumissem os produtos fabricados em massa que as corporações estavam por fabricar em quantidades cada vez maiores. Mas isso presumia que os trabalhadores soubessem como gastar seu dinheiro adequadamente. (2003, p. 122)

\section{FORDISMO/TAYLORISMO E KEYNESIANISMO}

O Estado desempenhou um papel bem definido nesse modelo de organização social: Estado interventor. Mediante inúmeros mecanismos de regulamentação estatal, o capitalismo alcançou um período de expansão, de 1930 até 1970, com taxas fortes, mas estáveis, de crescimento econômico. A aliança entre o fordismo/taylorismo e o planejamento estatal racionalizado decorre da experiência da profunda crise de 1929. No dia 24 de outubro do referido ano (conhecido como a "Quinta-Feira Negra") iniciou-se uma das piores catástrofes econômicas da história do capitalismo. O valor dos títulos negociados na Bolsa de Nova Iorque apresentou trajetória descendente, abalando a confiança na economia, fechando milhares de corporações e lançando ao desemprego milhões de trabalhadores.

Urgia tomar medidas drásticas que revertessem o processo de crise. John Maynard Keynes (1883-1946) postulou o seguinte: "para que o equilíbrio seja mantido no sistema econômico é preciso que o Estado tenha um papel constante de intervenção. Essa intervenção seria mais forte nos momentos em que o mercado não conseguisse superar as crises" (SANTOS, 1996, p. 100). Na visão keynesiana,

[...] quando a poupança excedesse os investimentos, o governo deveria entrar em cena, recolhendo o excesso de poupança mediante empréstimos e investindo o dinheiro em projetos de utilidade social (escolas, hospitais, parques e outras obras do gênero). A

\footnotetext{
15 Rago e Moreira (1993) apontam que, no fordismoltaylorismo, ocorre a eliminação do trabalho intelectual no chão da fábrica e sua centralização no departamento de planejamento. À direção compete dirigir, controlar e vigiar o trabalhador, impedindo, por todos os meios, sua articulação e comunicação horizontais no interior do espaço produtivo. Localizados em seus postos, os superiores hierárquicos dispõem de um observatório por meio do qual analisam, classificam, registram e produzem conhecimentos sobre o subordinado, o que facilita a vigilância e o controle sobre ele.

16 A avaliação da produtividade é materializada no cronômetro. Para cada movimento há um tempo ideal de duração, que permite premiar os mais produtivos e punir os "indolentes". A individualização dos salários constitui uma forma explícita de introduzir a competição entre os trabalhadores.
} 
escolha deveria recair sobre projetos que não ampliassem a capacidade produtiva da economia e, ao mesmo tempo, não reduzissem as oportunidades de emprego para o futuro. As despesas governamentais injetariam maiores recursos no fluxo de gastos e criariam condições para o estabelecimento do pleno emprego, sem alterar o estoque de capital. (HUNT; SHERMAN, 1988, p. 170)

O fordismo se aliou ao keynesianismo, e o capitalismo conheceu um surto de expansões internacionalistas de alcance mundial, tendo como ápice os Estados Unidos. Na leitura de Sader, "assim, o capitalismo cresceu mais justamente quando foi menos liberal, quando mais regulamentou a economia. Foi menos injusto quando foi menos liberal" (1997, p. 31) ${ }^{17}$. Com a conjunção fordismo/keynesianismo, os padrões de vida se elevaram, as tendências da crise foram contidas e a democracia de massa foi preservada. O Estado assumiu novos papéis e construiu novos poderes constitucionais. Desempenhou, no parecer de Harvey (2003), um papel intervencionista na esfera econômica para promover o crescimento estável, com o aumento dos padrões materiais de vida por meio da combinação entre Estado de Bem-Estar Social, administração econômica keynesiana ${ }^{18}$ e controle de relações de salário.

O Estado fundamentou suas ações em um tripé constituído por trabalho organizado, grande capital-corporativo e nação-Estado (HARVEY, 2003). Passou então a gerenciar as relações entre capital-trabalho, pressionando as organizações sindicais, por meio do processo de burocratização. Em relação aos sindicatos, esta representou um recuo do poder operário, uma vez que as organizações sindicais burocratizadas foram cada vez mais pressionadas para trocar ganhos reais de salários pela cooperação na disciplinação dos trabalhadores de acordo com o sistema fordista de produção (HARVEY, 2003). Muitos sindicatos passaram a se restringir à defesa dos interesses estreitos de seus afiliados, abandonando preocupações socialistas mais amplas. O pleno emprego tornou-se o símbolo de desmobilização do operariado europeu e americano. De acordo com Sader, "pressionados externamente pela existência da URSS e do chamado campo socialista, e, internamente, pela força dos partidos comunistas [...], os países capitalistas da Europa Ocidental tiveram que fazer concessões e nenhuma delas teve tanto peso como o pleno emprego" (1997, p. 32).

Convém sublinhar, entretanto, que inúmeras categorias sociais não encontraram resguardo e proteção às sombras do Estado keynesiano. Na constatação de Harvey (2003), uma parcela significativa dos trabalhadores dos países centrais do capitalismo ficou às margens da sociedade de consumo de massa, com suas demandas negligenciadas e sem acesso aos benefícios de seguridade, habitação, educação e saúde. As minorias raciais, étnicas e sexuais, mal-remuneradas, constantemente expressaram suas insatisfações e lutaram pela igualdade de direitos. Harvey (2003) assinalou que, por outro lado, os povos colonizados envolveram-se em movimentos de emancipação, objetivando libertar-se do jugo imperialista europeu e norteamericano. Os insatisfeitos do Terceiro Mundo, em sua ótica, constataram a discrepância entre as promessas de desenvolvimento e integração acenadas pelo fordismo e a realidade de domínio, opressão e destruição das culturas locais.

\footnotetext{
$17 \mathrm{Na}$ interpretação de Lima, "o newdeal norte-americano e o estado de bem-estar social na Europa Ocidental significaram, entre outras coisas, a intervenção do estado na reprodução de sua força de trabalho e na sua proteção frente à exploração capitalista, reproduzindo o ideal fordista de produção em massa para o consumo em massa" (2002, p. 18).

18 Com o término da Segunda Guerra Mundial, a teoria econômica keynesiana converteu-se em ortodoxia, tanto para os economistas quanto para a maioria dos políticos e governantes. As novas responsabilidades do Estado na regulamentação da economia e das relações de trabalho caracterizaram o chamado "Estado de bem-estar social". Lima (2002, p. 18) indica que "ao trabalho assalariado agregou-se uma série de mecanismos de proteção social que tornaram a condição operária nos EUA e Europa Ocidental atraente em comparação aos chamados Estados operários e subdesenvolvidos em geral”.
} 
Se o trabalho foi relativamente "domesticado" e os excluídos foram reprimidos, quando se manifestaram, as grandes corporações encontraram todas as condições necessárias para avançar sobre várias partes do globo, difundindo seu modelo de organização do trabalho como um padrão a ser seguido pelos países subdesenvolvidos ${ }^{19}$. As grandes corporações compõem um dos pilares do fordismo/taylorismo. Elas procuraram assegurar o crescimento sustentado de investimentos, aumentando a produtividade e mantendo uma base estável para a realização de lucros. Na apreciação de Harvey (2003), seu modelo de administração científica da produção expandiu-se para todas as facetas de seus negócios e relações (treinamento da mão de obra, recrutamento de clientes e parceiros, política de divulgação de produtos e serviços e marketing).

De modo simplificado, o fordismo pode ser caracterizado como produção em massa, consumo de massa, padronização, crescimento das unidades produtivas e, por extensão, da classe trabalhadora, fortalecimento do Estado-nação, elevado grau de especialização de tarefas, excessivo controle hierárquico, alienação, competitividade, desperdício, fadiga psicofísica e exploração. Eis a síntese de Bauman sobre o que considera "modernidade pesada":

\begin{abstract}
A "modernidade pesada" era o tempo do compromisso entre capital e trabalho, fortificado pela mutualidade de sua dependência. Os trabalhadores dependiam de empregos para terem seu sustento; o capital dependia de empregá-los para a sua reprodução e crescimento. Esse encontro tinha um endereço fixo; nenhum dos dois poderia se mover para outra parte com facilidade - as paredes maciças da fábrica mantinham ambos os sócios em uma prisão compartilhada. O capital e os trabalhadores estavam unidos, poderíamos dizer, na riqueza e na pobreza, na saúde e na doença, até que a morte os separasse. A fábrica era a residência comum deles - o campo de batalha para a guerra de trincheiras e o lar natural da esperança e dos sonhos. (2008b, p. 32)
\end{abstract}

\title{
7. DO FORDISMO À ACUMULAÇÃO FLEXÍVEL
}

De 1945 até finais da década de 1960, o sistema fordista-keynesiano difundiu seu conjunto de práticas de controle de trabalho, tecnologias, hábitos de consumo e configurações de poder político-econômico. A partir da década de 1970, esse sistema enfraqueceu e cedeu espaço para outro paradigma de produção e uso do trabalho. Tinha início um novo modelo de processos de trabalho com mercados mais flexíveis, com mobilidade geográfica e rápidas mudanças das práticas de consumo: o modelo de acumulação flexível.

Em 1973, com a "crise do petróleo", as contradições inerentes ao capitalismo se tornaram mais acirradas e evidentes. A grave crise econômica tornou patente a incapacidade do fordismo/keynesianismo, enquanto padrão de organização econômica, de recuperar o ciclo expansivo do capitalismo.

O fordismo, no parecer de Harvey, caracterizou-se pela rigidez:

Havia problemas com a rigidez dos investimentos do capital fixo de larga escala e de longo prazo em sistemas de produção em massa que impediam muita flexibilidade de planejamento e presumiam crescimento estável em mercados de consumo invariantes. Havia problemas com rigidez nos mercados, na alocação e nos contratos de trabalho

\footnotetext{
19 Instaladas em outros territórios, elas remetem os lucros para as matrizes localizadas nos países centrais do capitalismo. Amplia-se a assimetria na repartição do trabalho no mundo. Nas palavras de Pochmann, "no centro da economia mundial está o locus do poder de comando, sendo aí predominantes as atividades de controle do excedente das cadeias produtivas, bem como de produção e difusão de novas tecnologias. [...] Já na periferia, que assume um papel secundário na estrutura do poder mundial, está o locus subordinado de apropriação do excedente econômico e dependente na geração e absorção tecnológica" (2004, p. 21-22).
} 
(especialmente no chamado setor "monopolista"). [...]. A rigidez dos compromissos do Estado foi se intensificando a medida que programas de assistência (seguridade social, direitos de pensão etc.) aumentavam sob pressão para manter a legitimidade num momento em que a rigidez na produção restringia expansões da base fiscal para gastos públicos. (2003, p. 135-136)

No âmbito produtivo, a rigidez foi ilustrada pela diminuição do ritmo produtivo das grandes corporações. O mesmo Harvey (2003) sublinha que, em plenas condições de intensificação da competição, as corporações viram-se com muita capacidade excedente inutilizável, principalmente fábricas e equipamentos ociosos. Foram obrigadas então a conter seus interesses expansionistas, ingressando em um período de racionalização, reestruturação e intensificação do controle do trabalho. Sobre isso, o autor salienta que

A mudança tecnológica, a automação, a busca de novas linhas de produtos e nichos de mercado, a dispersão geográfica para zonas de controle do trabalho mais fácil, as fusões e medidas para acelerar o tempo de giro do capital passaram ao primeiro plano das estratégias corporativas de sobrevivência em condições gerais de deflação. (2003, p. 137)

No diagnóstico de Lima, a revolução informacional veio acompanhada de novos métodos de racionalização do trabalho que tiveram no Japão seu modelo: "flexibilidade produtiva, maior participação operária no processo de trabalho, enxugamento de custos, polivalência funcional, novo perfil do trabalhador, redes virtuosas de empresas com transferência de tecnologia" (2002, p. 19). No panorama de competitividade, argumenta o mesmo autor que a reengenharia, ou lean production, esteve ladeada pela redução de postos de trabalho ou downsizing. Completando o quadro, o processo de terceirização foi amplamente adotado na produção em fábricas distribuídas globalmente.

A (re)distribuição das empresas assumiu então uma dimensão global ${ }^{20}$. No começo dos anos 1970, houve uma expansão das indústrias multinacionais em direção à periferia do sistema capitalista, em busca de possibilidades mais rentáveis de investimento, em contraposição à rigidez das relações de trabalho e à força dos sindicatos nos países centrais. A expansão internacional e a racionalização das operações das corporações processaram-se por novas combinações entre os investimentos internacionais, o comércio e a cooperação entre empresas coligadas.

Assim, nas décadas de 1970 e 1980 mudanças significativas se verificaram. Na ótica de Antunes (apud ANTUNES, 1997), novos processos de trabalho emergiram, nos quais o cronômetro e a produção em série foram substituídos pela flexibilização da produção, por novos padrões de busca de produtividade, por novas formas de adequação à lógica do mercado. Na exposição de Harvey (2003), novas experiências nos domínios da organização industrial e da vida social e política.

O Estado fordista/keynesiano interventor, repleto de obrigações sociais, foi bombardeado pela ideologia neoliberal. Esse viés, que se torna hegemônico com o colapso da experiência soviética, afirma a necessidade de que a sociedade se adapte às novas exigências e obrigações, e, sobretudo, que descarte qualquer ideia de procurar orientar, dominar, controlar, canalizar esse novo processo. Chesnais constata que

\footnotetext{
20 Esse processo corresponde, no olhar de Haddad, à emergência da superindústria capitalista: “A superindústria enseja, então, um processo peculiar de internacionalização da economia, a imprecisamente chamada "globalização". A base técnica dessa operação é a telemática [...]” (1998, p. 28).
} 
[...] para os turiferários da globalização, a necessária adaptação pressupõe que a liberalização e a desregulamentação sejam levadas a cabo, que as empresas tenham absoluta liberdade de movimentos e que todos os campos da vida social, sem exceção, sejam submetidos à valorização do capital privado. $(1996$, p. 25)

O neoliberalismo pregou o Estado mínimo, asseverando a urgência na desconstrução do Estado de Bem-Estar Social ${ }^{21}$. Seguindo a lógica de Sader, verifica-se que o neoliberalismo, na condição de

[...] nova - e mais selvagem ainda - formulação da mão harmoniosa de um mercado exacerbado, deu o sinal de partida para a destituição dos direitos sociais e para gerir a maior onda de insegurança que o capitalismo já presenciou, desde que havia começado a socializar as pessoas mediante o trabalho assalariado e o contrato formal de trabalho. (1997, p. 62)

Enquanto elaboração conceitual que estabeleceu a hegemonia pragmática no fim da década de 1970, com os governos de Margaret Thatcher (eleita primeira-ministra da Grã Bretanha em 1979) e Ronald Reagan (presidente eleito dos Estados Unidos em 1980), o neoliberalismo é, segundo Harvey,

[...] uma teoria das práticas político-econômicas que propõe que o.bem-estar humano pode ser melhor promovido liberando-se as liberdades e capacidades empreendedoras individuais no âmbito de uma estrutura institucional caracterizada por sólidos direitos a propriedade privada, livres mercados e livre comércio. (2008, p. 12)

O neoliberalismo, na condição de prática político-econômica, empreendeu o que Harvey (2008) denominou de "destruição criativa". De modo crescente, ocorreu concentração de renda e riqueza nos estratos superiores da sociedade e nos países centrais da economia capitalista. Enquanto destruía, a neoliberalização reconstruía:

O processo de neoliberalização, no entanto, envolveu muita "destruição criativa", não somente dos antigos poderes e estruturas institucionais (chegando mesmo a abalar as formas tradicionais de soberania do Estado), mas também das divisões do trabalho, das relações sociais, da promoção do bem-estar social, das combinações de tecnologias, dos modos de vida e de pensamento, das atividades reprodutivas, das formas de ligação à terra e dos hábitos do coração. Na medida em que julga a troca de mercado "uma ética em si capaz de servir de guia a toda ação humana, e que substitui todas as crenças éticas antes sustentadas", o neoliberalismo enfatiza a significação das relações contratuais no mercado. Ele sustenta que o bem social é maximizado e se maximizam o alcance e a frequência das transações de mercado, procurando enquadrar todas as ações humanas no domínio do mercado (HARVEY, 2008, p. 13).

Conforme a explanação de Harvey, ocorreu, na economia, o aprofundamento e o domínio das finanças, assim como sobre o aparato do Estado:

O papel do Estado é criar e preservar uma estrutura institucional apropriada a essas práticas; o Estado tem de garantir, por exemplo, a qualidade e a integridade do dinheiro. Deve também estabelecer as estruturas e funções militares, de defesa, da polícia e

\footnotetext{
${ }^{21}$ A respeito do desmonte do Estado de Bem-Estar Social, Araújo (2001) observa um paradoxo no argumento e nas práticas neoliberais. Se, de um lado, as grandes potências, por intermédio do Banco Mundial e do FMI (Fundo Monetário Internacional), impõem políticas rigorosas de ajustes fiscais aos países periféricos, enfraquecendo a soberania nacional desses Estados, de outro, os Estados centrais continuam sendo os articuladores dos interesses de seus capitais (produtivos e especulativos) por meio de uma série de políticas e mecanismos protecionistas.
} 
legais requeridas para garantir direitos de propriedade individuais e para assegurar, se necessário pela força, o funcionamento apropriado dos mercados. Além disso, se não existirem mercados (em áreas como a terra, a água, a instrução, o cuidado de saúde, a segurança social ou a poluição ambiental), estes devem ser criados, se necessário pela ação do Estado. Mas o Estado não deve aventurar-se para além dessas tarefas. As intervenções do Estado nos mercados (uma vez criados) devem ser mantidas num nível mínimo, porque, de acordo com a teoria, o Estado possivelmente não possui informações suficientes para entender devidamente os sinais do mercado (preços) e porque poderosos grupos de interesse vão inevitavelmente distorcer e viciar as intervenções do Estado (particularmente nas democracias) em seu próprio benefício. (2008, p. 12)

Nas palavras do autor, o Estado neoliberal se orienta pelo princípio de que, no caso de conflito entre, de um lado, os interesses das instituições financeiras (e os rendimentos dos detentores de títulos) e o bem-estar da coletividade, de outro, o aparato do Estado deve primar pelo resguardo dos combatentes do primeiro flanco. Com a desregulamentação dos mercados, sua descompartimentação e a falta de mediação restritiva, multiplicaram-se as possibilidades "de lucros puramente especulativos, por meio dos quais o capital cresce sem passar por um investimento em atividades produtivas" (BOLTANSKI; CHIAPELLO, 2009, p. 21).

A afirmação do neoliberalismo como ideologia da nova fase histórica do sistema capitalista, em escala planetária, tem no conceito de globalização um de seus principais postulados. No entanto, argumenta Chesnais (1996), uma análise crítica possibilita verificar que os termos global e globalização não são neutros ideologicamente. São cheios de conotações e, ao mesmo tempo, vagos, cabendo-lhes um conteúdo de acordo com a conveniência. A palavra globalização mostra-se insuficiente para abarcar a totalidade do processo, pois contempla um aspecto do fenômeno e sua utilização, mais do que ser uma meia-verdade, reveste o caráter de manipulação ideológica.

O conceito de globalização não receberá o devido tratamento no corpo exíguo deste trabalho. De modo sucinto, na apreciação de Bauman (1999; 2008b), o conceito de globalização foi cunhado para substituir o conceito de universalização, que indica processos planejados. Globalização se refere à natureza desordenada dos processos que ocorrem acima dos territórios nacionais, acima do Estado-nação.

Com a alardeada globalização, observa-se a reconstituição de uma hierarquia de espaços produtivos, um acirramento da divisão internacional do trabalho e um aumento ainda maior das especializações tecnológicas. Em sua análise, Santos pondera que

A mundialização que se vê é perversa. Concentração e centralização da economia e do poder político, cultura de massa, cientificização da burocracia, centralização agravada das decisões e da informação, tudo isso forma a base de um acirramento das desigualdades entre países e entre classes sociais, assim como da opressão e da desintegração do indivíduo. (1996, p. 17)

Não há concordância entre globalização e homogeneização dos espaços mundiais, mas, ao contrário, diferenciação e especialização ${ }^{22}$. O que se verifica é a sedimentação de uma divisão mundial capitalista do trabalho, fundada no desenvolvimento das forças produtivas em escala mundial e conduzida por meio das potências centrais e das corporações transnacionais.

\footnotetext{
22 Pochmann discursa no mesmo tom: "São cada vez maiores os sinais de que o processo de globalização financeira, em marcha a partir do último quartel do século XX, não tem resultado em maior simetria entre nações ricas e pobres. E nota-se que a ampliação da distância que separa as nações está direta e indiretamente relacionada à conformação de uma nova Divisão Internacional do Trabalho" (2004, p. 15).
} 
A globalização vivenciada em conexão com a neoliberalização é apreciada como "negativa unilateral" por Bauman (1999; 2008a; 2008b), que assim a resume:

Em sua forma atual, puramente negativa, a globalização é um processo parasitário e predatório que se alimenta da energia extraída dos corpos dos Estados-nação e outros dispositivos de proteção de que seus súditos já usufruíram (e dos quais ocasionalmente foram vítimas) no passado. (2008a, p. 189)

Em diapasão uníssono, o mesmo autor se expressa sobre a relação entre globalização e pobreza:

Sabe-se que libertada das rédeas políticas e das restrições locais, a economia rapidamente globalizada e crescentemente extraterritorial produz lacunas de riqueza e renda cada vez mais profundas entre as nações da população mundial em melhor e pior situação e dentro de cada sociedade. Ela também é conhecida por lançar pedaços cada vez maiores da população na pobreza e por torná-las permanentemente evictos de qualquer trabalho reconhecido socialmente como racional em terrenos econômicos e útil em termos sociais, tornando-se, assim, econômica e socialmente redundantes. (2008b, p. 148)

\section{TOYOTISMO OU ACUMULAÇÃO FLEXÍVEL}

Como indicado anteriormente, a partir da década de 1970 modificações na ordem econômica resultaram em um processo de ajuste macroeconômico e reestruturação microorganizacional. A apreensão analítica do toyotismo, ou acumulação flexível, exige as mesmas considerações efetivadas a respeito do fordismo/taylorismo. Afinal, o toyotismo não se restringe a um simples modelo de organização e gestão de trabalho no interior das empresas. Não se limita a uma aplicação mecânica de métodos e técnicas de produção japonesas ${ }^{23}$. O toyotismo somente é compreensível quando referido a outros traços e modificações: nova demanda dos mercados, nova estrutura empregatícia, novas relações no local de trabalho, novos parâmetros de relação sentimental entre indivíduos ${ }^{24}$ e novas relações entre empresários, trabalhadores e o Estado.

23 Após a Segunda Guerra Mundial, para recuperar-se dos prejuízos da derrota, a economia japonesa teve a necessidade de produzir com poucos recursos, potencializando processos e reduzindo ao máximo os desperdícios. O modelo de produção enxuta desenvolveu-se como sistema de manufatura na Toyota e edificou-se na filosofia de eliminação dos desperdícios dentro da organização, como superprodução, espera, transporte excessivo, processos inadequados, inventário desnecessário, movimentação desnecessária e produtos defeituosos. Inúmeras discussões foram travadas a respeito da adoção do toyotismo fora do Japão. Pode-se tratar como uma questão de difusão do just in time? Wood argumenta que os aspectos culturais que contribuíram para a reconstrução do Japão no pós-guerra devem ser levados em consideração quando se falar em toyotização ou japonização. Assim, "o toyotismo é caracterizado não apenas com base na eliminação de estoques de reserva (buffers) e em procedimentos just in time, mas também por causa das 'relações humanas' que fornecem a base para o 'controle de qualidade total' e o envolvimento dos trabalhadores" (1993, p. 53).

24 Análise salutar a respeito do novo dimensionamento das relações sentimentais interpessoais é empreendida por Bauman (2004). O sociólogo em apreço reflete sobre a fragilidade dos laços humanos no momento da história por ele denominado de "modernidade líquida". A fluidez do capital, a volatilidade do mercado, a rapidez da informação e a obsolescência dos produtos se combinam na conformação de uma nova lógica: a lógica do consumidor. Tal qual a relação de escolha, compra e descarte realizada entre consumidor e mercadoria, a relação entre indivíduos se conforma pela volatilidade, pela oportunidade, pela efemeridade e pelo descarte tão logo novas oportunidades são descortinadas no horizonte. De acordo com o autor, os indivíduos temem laços duradouros, não assumem as responsabilidades decorrentes de tais vínculos e escolhem parceiros como se escolhessem mercadorias em prateleiras de supermercados. 
A reestruturação produtiva, ou reengenharia, caracteriza-se pela adoção de técnicas altamente desenvolvidas (a automação), pela exigência de qualificação dos operários e pela busca de flexibilidade e adaptação. Em um cenário de acirrada competitividade, as grandes corporações implantaram inovações tecnológicas que visavam aumentar a eficiência, reduzindo custos do trabalho, aprimorando a produção e a oferta de bens e serviços e garantido rentabilidade. Ao lado da adoção dos métodos e técnicas da "produção enxuta" substituem-se ${ }^{25}$ as políticas repressivas de gestão do trabalho por formas menos conflituosas, que possibilitam às empresas contar com a colaboração dos trabalhadores na busca de qualidade e produtividade.

Enquanto novo paradigma de organização industrial e, por extensão, de relações de trabalho, o chamado modelo de acumulação flexível se contrapõe à tradição fordista/ taylorista. Se o fordismo pressupõe rigidez, o toyotismo representaria inovação, adaptabilidade e flexibilidade dos processos e mercados de trabalho, dos produtos e dos padrões de consumo (HARVEY, 2003). "A flexibilidade é apresentada como uma panaceia, como oposição à rigidez, como sinônimo de capacidade de adaptação, maleabilidade, modernidade" (MEULDERS apud HIRATA; MARUANI, 2003, p. 273). Flexibilidade na produção por meio da adoção do sistema Just in time: o movimento sendo puxado do fim da linha de montagem, de modo a inverter os parâmetros do fordismo/taylorismo da produção em massa ${ }^{26}$.

Inovação comercial, tecnológica e organizacional favorecida pelo desenvolvimento dos meios de transporte e de comunicação. Na linha de Haddad (1998), a denominada "teleinformática", ou "telemática", possibilitou a queda nos custos e a difusão imediata das decisões das grandes corporações em um espaço cada vez mais amplo e variegado. Ocorreu, no diagnóstico de Harvey (2003), uma compressão do espaço-tempo, com intensificação das interações e aumento da velocidade do fluxo de relações, serviços e produtos que transcendem os limites das sociedades e Estados nacionais.

Outro dado característico das últimas décadas é o surgimento de setores de produção inteiramente novos, com novas maneiras de fornecimento de serviços financeiros e novos mercados, nos quais ocorre o abandono do padrão das enormes unidades fabris, abrangendo milhares de trabalhadores. Concomitantemente às inovações tecnológicas, observa-se um vasto movimento de empregabilidade no "setor de serviços", bem como conjuntos industriais completamente adventícios em regiões até então subdesenvolvidas (HARVEY, 2003, p. 140).

Conforme assinalado anteriormente, a distribuição de células das grandes corporações por regiões dos países periféricos não corresponde a uma distribuição da riqueza. Pelo contrário, verifica-se um desenvolvimento desigual entre setores produtivos e entre regiões geográficas. A “inclusão", no fluxo da economia internacionalizada, de áreas outrora marginais do processo produtivo se enquadra na busca da redução de custos pelas corporações, pois permite o barateamento da mão de obra. Ao apropriar-se da força de trabalho vulnerável dos países periféricos, o capital torna precário o trabalho organizado nos países centrais. Afinal, é

25 É necessário relativizar a afirmação de que ocorreu uma substituição da hierarquia despótica da fábrica fordista. O ritmo de avanço e adoção do toyotismo variou entre os países e entre os setores produtivos.

${ }_{26} \mathrm{O}$ método just in time desenvolveu-se como um meio de aumentar a utilização da capacidade produtiva, reduzindo os tamanhos dos lotes sem incorrer em gastos desnecessários e minimizando os tempos de mudança. O sistema de produção japonês parece inverter os princípios fordistas: "é possível produzir eficientemente com lotes menores de produção; a minimização de estoques intermediários e o suprimento just in time de partes 'perfeitas' aumentam o rendimento do processo; a qualidade pode ser aperfeiçoada sem custos adicionais" (WOOD, 2003, p. 54). Segundo alguns pensadores, o que o just in time inverte não são os princípios fordistas da produção em massa, mas os meios convencionais de operacionalizá-los. O just in time é um instrumento de controle da produção que busca atender à demanda da maneira mais rápida possível e minimizar os vários tipos de estoque da empresa (intermediários, finais e de matéria-prima). 
mais rentável e mais cômodo para o capital-corporativo explorar a mão de obra barata e sem tradição organizativa em países em que a legislação trabalhista é maleável ou inexistente do que explorar a mão de obra organizada e combativa dos países onde a legislação trabalhista é devidamente cumprida (LIMA, 2002).

A reestruturação promove uma diminuição acentuada no número de postos de trabalho, levando ao quadro de desemprego estrutural. A força de trabalho viu o desemprego aumentar nos países capitalistas centrais em níveis sem precedentes, por outro lado, de modo correlato, os empregadores, fortalecidos pela flexibilidade e mobilidade, exercem pressões mais fortes de controle sobre essa força de trabalho vulnerável e desguarnecida ${ }^{27}$. $\mathrm{Na}$ assertiva de Harvey:

A acumulação flexível parece implicar níveis relativamente altos de desemprego “estrutural" (em oposição a "friccional'), rápida destruição e reconstrução das habilidades, ganhos modestos (quando há) de salários reais [...] e o retrocesso do poder sindical - uma das colunas políticas do regime fordista [...].(2003, p. 24)

O modelo de acumulação flexível promove uma transformação na estrutura do mercado de trabalho: o crescimento incessante do trabalho morto (máquinas) e a diminuição do trabalho vivo (homem) ${ }^{28}$. Nessa perspectiva, a modernização da base produtiva, mediante a mecanização atual das atividades, seria uma consequência lógica desse processo. Com a utilização das máquinas houve um acréscimo substantivo da produtividade do trabalho. $\mathrm{O}$ processo de valorização do capital via automação sinalizou a superação da fase histórica, na qual a exploração de mão de obra era essencial à reprodução do capital. Daí as discussões a respeito da centralidade do trabalho.

Em todos os setores produtivos, primários, secundários e terciários, para o capital, em seu estágio atual, torna-se desvantajosa a utilização do operário em relação à máquina, mesmo que esse trabalhador ocupe uma posição desfavorecida no mercado, disponha de baixa capacidade de barganha na venda de sua força de trabalho e, via de regra, aceite trabalhar por qualquer preço e em quaisquer condições. Em alguns segmentos, como o corte de cana no Estado de São Paulo, a reestruturação produtiva nas empresas rurais caracteriza-se pela adoção de estratégias inovadoras para flexibilizar a organização e o controle do capital humano, integrando todas as etapas do processo produtivo e de circulação: plantio, tratos culturais, colheita, beneficiamento, transporte e comercialização dos produtos agrícolas. Todos os momentos são permeados por intensa racionalização tecnológica, com o desenvolvimento de pacotes modernos de insumos e maquinários, acrescidos de logística eficiente. Processo, este, coroado pela substituição da

\footnotetext{
27 A estratégia sindical atual é distinta de uma atuação combativa e de mobilização. No presente, a principal questão na agenda sindical é a defesa do emprego, a participação nos resultados, a discussão das mudanças de gestão e organização do trabalho, a flexibilização da jornada e a mudança na legislação trabalhista. Antunes aponta que, no Brasil, "os sindicatos estão aturdidos e exercitando uma prática que raramente foi tão defensiva. Abandonando o sindicalismo de classe dos anos 60 e 70, aderindo ao acrítico sindicalismo de participação e de negociação, que em geral aceita a ordem do capital e do mercado, só questionando aspectos fenomênicos desta mesma ordem. Abandonam as perspectivas emancipatórias, da luta pelo socialismo e pela emancipação do gênero humano, operando uma aceitação também acrítica da 'social-democratização', ou o que é ainda mais perverso, debatendo no universo da agenda e do ideário neoliberal [...] Esquecem a luta pelo controle social da produção, tão intensa nos anos 60/70, e subordinam-se à ação pela participação dentro da ordem. Tramam sua ação dentro dos valores fornecidos pela sociabilidade do mercado e do capital" (apud ANTUNES, 1997, p. 72).

28 Antunes (apud ANTUNES, 1997) explica que com a introdução da automação, da robótica e da flexibilização houve uma alteração qualitativa da forma de ser do trabalho. A redução da dimensão variável do capital em decorrência de sua dimensão constante - ou, em outras palavras, a substituição do trabalho vivo pelo trabalho morto - oferece, como tendência, a possibilidade da conversão do trabalhador em supervisor e regulador do processo produtivo. Todavia, sob o capitalismo, mesmo com o impacto tecnológico, não se constata o fim do trabalho como medida de valor, mas uma mudança qualitativa, dada pelo peso crescente da dimensão da qualificação do trabalho.
} 
administração de caráter pessoal, familiar e tradicional pela administração formal, impessoal e objetiva da gerência.

$\mathrm{Na}$ esfera do trabalho agrícola, a reestruturação produtiva é vivenciada como concorrência dos trabalhadores com as máquinas, nas diversas atividades, além da precarização dos direitos trabalhistas. Acossados pela ameaça das inovações e renitentes em manter seus postos, os trabalhadores volantes do corte de cana enquadram-se nas novas exigências de produtividade, aceitando a precarização do trabalho como única via de sobrevivência. A elevação das metas de produtividade se fez acompanhar de novos critérios de seleção: idade, escolaridade, sexo, passividade política ou ausência de vínculos sindicais, condições de saúde, lugar de origem etc. Em virtude do vertiginoso processo de mecanização da agricultura paulista, os trabalhadores são submetidos a um intensíssimo ritmo de trabalho que esgota suas capacidades físicas em um curto espaço de tempo, havendo o consumo não somente da força de trabalho, como também do próprio trabalhador.

A elevação das metas de produtividade nos últimos tempos - cinco toneladas na década de 1980, nove toneladas na década de 1990 e 12 toneladas nos anos 2000 - foi responsável pelo esforço físico repetitivo e extenuante. Nas décadas de 2000 e 2010, inúmeras mortes de trabalhadores canavieiros foram associadas ao excesso de trabalho. Para conseguir ganhar o suficiente, pois o ganho é por produção, os trabalhadores se obrigam a colher até 18 toneladas por $\operatorname{dia}^{29}$.

Em todos os setores da atividade produtiva verificou-se real diminuição do número de pessoas empregadas. As relações de trabalho se transformaram. Ocorreu, também, uma mudança na família e na sociedade. "O emprego, sinônimo de trabalho assalariado, carteira profissional e direitos sociais, aparece cada vez mais como coisa de um passado remoto" (LIMA, 2002, p. 21). Como exemplificação da mudança na estrutura do trabalho, podemos citar o processo verificado na indústria metalúrgica do $\mathrm{ABC}$, um dos pólos sindicais mais influentes e combativos. De 1987 a 1996, ocorreu uma diminuição de 82.430 postos de trabalho, passando de 203.111 empregados para 120.681 . Isso representa uma redução de $40 \%$ de toda a mão de obra empregada do setor metalúrgico da região. Harvey indica que

O mercado de trabalho passou por uma radical reestruturação. Diante da forte volatilidade do mercado, do aumento da competição e do estreitamento das margens de lucro, os patrões tiraram proveito do enfraquecimento do poder sindical e da grande quantidade da mão de obra excedente (desempregados ou subempregados) para impor regimes e contratos de trabalho mais flexíveis. (2003, p. 143)

Desta feita, a outra face da reestruturação produtiva, tão preocupante quanto o desemprego manifesto, é a precarização do trabalho. No que tange às atividades industriais, essa face comporta a terceirização $o^{30}$, com a gradativa perda dos direitos conseguidos. Volta-se a atenção para a necessidade das empresas de reduzirem os custos sociais do trabalho registrado. Processa-se uma proliferação de "cooperativas", como empresas de subcontratação de mão de obra, representando a negação dos direitos trabalhistas assegurados ${ }^{31}$. A terceirização ou subcontratação de pequenas empresas protege as grandes corporações dos custos de flutuação

29 Silva (2008; 2006; 1999), Verçoza (2016) e Guanais (2016; apud SILVA; VERÇOZA, 2020) apresentam ricas contribuições para o entendimento das condições de vida, trabalho e saúde dos assalariados do corte da cana.

${ }^{30}$ A terceirização corresponde ao processo de focalização das empresas no produto principal e a externalização de atividades consideradas secundárias dentro do paradigma da flexibilização: empresas menores com tecnologia e organização do trabalho tradicionais, trabalhadores mais baratos e menores custos de produção.

31 Os empresários enfatizam as vantagens do mercado desregulamentado. Alegam que os trabalhadores podem encontrar maior facilidade de inserção no mercado e de troca de determinados empregos e carreiras. 
do mercado. A tendência é, nos dizeres de Harvey, "empregar cada vez mais uma força de trabalho que entra facilmente e é demitida sem custos quando as coisas ficam ruins" (2003, p. 144).

A terceirização corresponde ao processo de focalização das empresas no produto principal e a externalização de atividades consideradas secundárias dentro do paradigma da flexibilização: empresas menores com tecnologia e organização do trabalho tradicionais, trabalhadores mais baratos e menores custos de produção. Em nome da produtividade e da competitividade, atribuem-se a firmas terceiras tarefas anteriormente realizadas pelas empresas principais. No entanto, diante de um mercado de trabalho com grande disponibilidade de mão de obra, a economia de custos tem efeitos devastadores sobre a oferta de emprego, com o agravamento das condições de trabalho e o aumento da informalidade (RAMALHO, apud ANTUNES, 1997). As empresas primeiras não assumem o ônus dos custos sociais do trabalho registrado, e as empresas terceiras, geralmente, burlam a legislação e são as grandes responsáveis pela precarização e vulnerabilidade do trabalho.

A redução do emprego regular em favor do crescimento do uso do trabalho em tempo parcial, temporário ou subcontratado, é a contundente manifestação dessa precarização. Para Harvey (2003), mesmo os trabalhos com elevada qualificação, que gozavam de maior segurança no emprego, boas perspectivas de promoção e de reciclagem, e de uma pensão, um seguro e outras vantagens, foram tragados pela dinâmica da precarização. Foram inseridos no movimento, denominado por Castel (1998) de "desestabilização dos estáveis" e "não empregabilidade dos qualificados".

O quadro social atual da flexibilização ou toyotização delineia-se com os seguintes traços: desemprego, exclusão, transformação de trabalhadores de contrato de tempo integral em tempo parcial, em seres humanos itinerantes à busca de emprego e superexploração da força de trabalho. Hoje em dia, cada vez mais gente está sendo empurrada para as fronteiras do mercado de trabalho, tendo de lutar para voltar (e, caso consiga, com poucas garantias de estabilidade).

Gradativamente, a frequência a cursos de qualificação e especialização não tem garantido a manutenção e a consecução de postos laborais por parte dos operários. A concorrência é tamanha, de forma que o indivíduo nunca se sente em condições ideais de conquistar seu espaço. Esse quadro, todavia, não é elucidado criticamente. Ele não é apresentado como resultado das transformações na sociedade, mas como incapacidade do próprio indivíduo. Dizem-lhe, frente à demissão ou à recusa para um cargo, que ele não deve se desesperar, mas buscar melhor qualificação. A culpa recai sobre o indivíduo. Empurra-se para os trabalhadores expulsos de seus postos a responsabilidade por essa perda, devido à desqualificação para os novos requerimentos do mercado (SADER, 1997). Ocorre um reencetamento do darwinismo social como ideologia. Os melhores sobreviverão pelo mérito.

Nas palavras de Harvey (2008), o sucesso e o fracasso individuais são interpretados, na lógica neoliberal, em termos de virtudes empreendedoras ou de falhas pessoais. $\mathrm{O}$ discurso de que os detentores de méritos garantem sua empregabilidade e os demais são descartados justifica as desigualdades sistêmicas. A ideologia da meritocracia oculta, na visão de Souza, o caráter de classe da desigualdade:

Esse é, no entanto, o "segredo" mais bem guardado do mundo moderno. Toda a "legitimação" social e política de qualquer sociedade moderna, seja ela central ou periférica, reside, precisamente, na cuidadosa negação do caráter de classe da desigualdade social moderna. Desse modo, a desigualdade tem que assumir uma forma "individual" para ser legítima. Essa forma individualizada de desigualdade, 
construída para negar a forma real e efetiva da produção classística da desigualdade, é exatamente a "ideologia da meritocracia". Segundo essa ideologia, a desigualdade é "justa" e "legítima" quando reflete o "mérito" diferencial dos indivíduos. Nada, aparentemente, mais justo. (2009, p. 120)

Os desempregados experimentam o tempo livre como tempo de angústia, desespero e persistente peregrinação, de empresa a empresa, em busca de sustento. Sobre o desempregado, a sociedade, ainda orientada valorativamente pelo mundo do trabalho, descarrega um pesado fardo. O antigo operário que provia a família passa a ser olhado com desdém e recriminações. Gradativamente, ele perde os laços com os antigos companheiros de serviço, pois já não partilha o cotidiano de trabalho na fábrica, além do fato de sentir-se envergonhado perante os ex-companheiros ${ }^{32}$. Perde seu respaldo e status social junto à própria família, a esposa e os filhos. Esse enjeitado da sociedade acaba interiorizando a negação e, consequentemente, deixa de alimentar a crença na própria capacidade: sente-se impotente. Torna-se amargo ou resigna-se perante as circunstâncias adversas que tendem a se tornar permanentes. Isso é a subjetivação da experiência da redundância, da inimpregabilidade.

\section{A HEGEMONIA DO SETOR DE SERVIÇOS E A PRECARIZAÇÃO DO TRABALHO}

$\mathrm{Na}$ interpretação de Masi (2000), é provável que um dos novos traços distintivos do novo sistema social seja exatamente o fato de ser policêntrico: baseia-se em uma estrutura reticulada de processos e de elementos, nenhum dos quais, em si, poderia determinar a dinâmica do todo. Todavia, ao analisar a realidade do capitalismo atual, constata-se uma redução do número de trabalhadores do setor industrial, ao mesmo tempo em que ocorre um crescimento quantitativo e qualitativo da produção de bens industrializados. Desse modo, uma sociedade não mais centrada na indústria dispõe dos produtos industriais em uma quantidade muito maior do que ocorria anteriormente ${ }^{33}$.

De acordo com Masi (2000), por outro lado ocorre a predominância quantitativa de pessoas voltadas para o setor de serviços, tanto privados como públicos: os serviços para as empresas (relacionados de modo considerável à inovação tecnológica e organizacional em todos os ramos de atividade econômica); os serviços de saúde, tanto hospitalares como não hospitalares; os serviços profisssionais; os serviços na área do ensino particular e os serviços de lazer. As pessoas hoje, predominantemente, trabalham em escritórios, lojas, companhias de seguro, organizações educacionais, hospitais, clínicas, bancos, comércio varejista etc. Ao lado do terciário tradicional temos o quaternário (sindicatos, bancos, seguradoras) e o quinário (serviços de saúde, educação, pesquisa científica, lazer, administração pública).

Os apologistas do neoliberalismo enxergam no crescimento do setor de serviços a composição de um eficaz instrumento gerencial e administrativo para adequar a força de trabalho às novas demandas de qualificação requeridas pela atual reestruturação empresarial. Os céticos, em outra direção, apontam para as contradições do próprio processo de expansão

\footnotetext{
32 "A saída do emprego, sem o restabelecimento de um outro vínculo de trabalho protegido e formalmente registrado, parece pôr em risco, para uma ampla gama de indivíduos, identidades sociais e formas de sociabilidade construídas em experiências pregressas de trabalho" (GUIMARÃES, 2004, p. 256).

${ }^{33}$ Na verificação de Guimarães, "a conjunção entre crescimento da produção, da produtividade e da competividade industriais, por um lado, e queda sistemática do emprego industrial, por outro, tornou-se um dos principais desafios interpretativos para a Sociologia do Trabalho Industrial no Brasil, a partir dos anos 90. (2004, p. 256)"
} 
do setor de serviços. Cavalcante e Wolff (2007) demonstram a precarização e a vulnerabilidade dos trabalhadores no setor administrativo, sobretudo, na área gerencial.

Outro ponto elucidado pelas correntes críticas corresponde ao fato de que o crescimento no setor de serviços se encontra vinculado aos processos de terceirização e de informalização do trabalho. Assim, ao lado do setor de serviços da economia formal, no qual o trabalho é regulamentado, garantido, sujeito à lei e promovedor de aposentadoria, cresce em grande proporção o trabalho na economia informal (subterrânea e doméstica).

A transformação da estrutura do mercado de trabalho apresenta simbiose com mudanças de igual importância na organização industrial. Por exemplo, a subcontratação organizada abriu oportunidades para a formação de pequenos negócios e, em alguns casos, permitiu, na indicação de Harvey (2003), que sistemas mais antigos de trabalho doméstico, artesanal, familiar (patriarcal) e paternalista ("padrinhos") revivessem e florescessem, mas agora como peças centrais, e não apêndices do sistema produtivo.

O trabalho em domicílio permite, às empresas, a transferência dos custos sociais do emprego para os trabalhadores e transforma a relação entre as partes em uma compra e venda de serviços entre produtores independentes. Esse tipo de trabalho aumenta como reação às exigências de uma força de trabalho flexível por parte da indústria e do setor de serviços (RAMALHO apud ANTUNES, 1997, p. 102).

No trabalho em domicílio, ocorre a preponderância expressiva de mão de obra feminina. $\mathrm{Na}$ conjuntura da reestruturação, segundo o entendimento de Ramalho,

O trabalho feminino domiciliar reforça a ideologia da domesticidade: o trabalho precário se naturaliza como uma espécie de extensão das funções domésticas de ajuda e complementação da renda familiar. $\mathrm{O}$ fato de trabalhar isoladamente, sem possibilidades de carreira ou promoção, ignoradas pelos sindicatos e sem benefícios sociais, faz com que as mulheres trabalhadoras tenham grandes dificuldades para diferenciar a sua atividade profissional daquela de mãe e esposa. (apud ANTUNES, 1997, p. 89)

Realmente, as novas estruturas do mercado de trabalho facilitam muito a participação das mulheres. Só que a exploração da força de trabalho das mulheres ocorre, predominantemente, em ocupações de tempo parcial, sob forte pressão e ritmo de trabalho imposto, seja por uma linha de montagem, seja pela supervisão dos chefes:

As mulheres são sobrerrepresentadas nessas formas particulares de emprego: seu acesso ao mercado de trabalho ocorre principalmente pelo viés de empregos atípicos particularmente desfavoráveis em termos de status, remuneração, horários e perspectivas de progresso. (MEULDERS apud HIRATA; MARUANI, 2003, p. 280)

O trabalho feminino é extremamente mal pago, não obstante o setor de serviços absorva a mão de obra feminina em quantidade superior à masculina. A mulher é a grande vítima da precarização do trabalho, pois, como desvenda Walby (apud HIRATA; MARUANI, 2003), ocorrem diferenciações ditadas pelo sexo nas políticas de organização do trabalho. Relações sociais de gênero permeiam e determinam as formas diferenciadas de inserção de homens e 
mulheres no mercado de trabalho, como reflexo da permanência de relações patriarcais na sociedade ${ }^{34}$.

O crescimento de formas de trabalho familiares e domésticas também coloca, na abordagem de Ramalho (apud ANTUNES, 1997, p. 86), uma redefinição no papel dos sindicatos. Estes, enquanto instituições representativas dos setores laborais, alicerçaram sua atuação no contato com trabalhadores concentrados em unidades produtivas. Trabalhadores, estes, com vínculos empregatícios formais. Ao se depararem com as modalidades de trabalho doméstico, temporário, parcial, subterrâneo, tais entidades encontram dificuldades de acesso e de mobilização dos trabalhadores. O restabelecimento das formas precárias e domésticas de trabalho favorece o solapamento da organização da classe trabalhadora e a transformação da base objetiva da luta de classes. Nelas, a consciência de classe já não deriva da clara relação de classe entre capital e trabalho (RAMALHO apud ANTUNES, 1997).

\section{NOVA TEORIA DAS CLASSES SOCIAIS}

Um dos desafios colocados à Sociologia, pelas transformações processadas na organização socioeconômica, incide na configuração da estratificação dos sujeitos sociais. A tese marxista de polarização de duas classes encontra reiteradas refutações, em amplos espectros teóricos. A teoria marxista de classe colocou sob a rubrica de proletariado a massa de trabalhadores que vendia sua força de trabalho diretamente ao capital e colocou sob a rubrica de burguesia os capitalistas, a alta gerência e os proprietários fundiários. Masi (2000) considera que ocorreu um declínio da luta de classe polarizada, substituída por uma pluralidade de conflitos e de movimentos, devido à presença de novos sujeitos sociais (conflitos de gênero, de raça, ecológicos etc.) $)^{35}$.

Beynon (1996), refletindo sobre o uso do conceito classe social como base de análise da sociedade e da mudança, aponta que a noção de classes é, simultaneamente, o mais útil e o mais problemático dos conceitos usados por historiadores e cientistas sociais. Desse modo, elaborar uma teoria de classes mais complexa que a teoria marxista "não permite declará-la per se mais fiel a uma realidade mais complexa; ela pode muito bem ser apenas mais confusa, se lhe falta o método adequado" (HADDAD, 1998, p. 19).

Do ponto de vista da teoria das classes, uma alteração do processo produtivo trouxe modificações: a transformação da ciência em fator de produção. A partir da Segunda Guerra Mundial, esse fator influiu decisivamente na configuração social. Essa alteração da produção jogou um papel-chave na contemporaneidade: o progresso técnico e científico mostra-se inerente ao processo de autovalorização do capital. Este, por sua vez, acaba por endogeneizar o processo de produção da própria ciência e tecnologia. Ocorre a criação, nas

\footnotetext{
34 “O caráter sexuado não se limita às políticas que regulamentam a igualdade de oportunidades no emprego nem às que tentam facilitar a conciliação entre a vida profissional e vida familiar. Ele se estende às políticas de regulamentação e de flexibilização do mercado de trabalho, já que a flexibilidade é um fenômeno sexuado, como toda tentativa que visa desenvolver políticas sobre as condições de emprego, num contexto social em que o acesso a empregos é repartido desigualmente entre homens e mulheres. Assim, as políticas de desregulação, introduzidas num esquema de competitividade acirrada, apoiam em geral nas desigualdades entre os sexos. A estratégia de desregulamentação que visa aumentar a competitividade é, de fato, uma estratégia sexuada" (WALBY apud HIRATA; MARUANI, 2003, p. 296).

35 O discurso neoliberal otimista enfatiza que, na sociedade "pós-industrial", o desenvolvimento dos meios de comunicação teria potencializado o acesso e a divulgação democráticos de opiniões, valores e modos de vida, de tal maneira que, múltiplas vozes se manifestam; uma polifonia. Os críticos marxistas frisam que os meios midiáticos encontram-se concentrados e conspiram contra a real democratização, primando pela homogeneização de ideias e modos de vida.
} 
empresas capitalistas, dos Departamentos de Pesquisa e Desenvolvimento. "Trata-se agora de uma verdadeira interdependência entre a ciência e a técnica [...]. Este é um dado fundamental da situação atual [...] o trabalho científico foi praticamente colocado a serviço da produção" (SANTOS, 1996, p. 17).

Levando em consideração essa importante modificação do processo produtivo, Haddad (1998) propõe uma teoria de classes que mantém, em um plano mais geral, certa visão dicotômica. Coloca proprietários de um lado e não proprietários de outro, porém assinala a heterogeneidade que envolve esses últimos:

1. A classe dos capitalistas: os proprietários dos meios de produção (capital financeiro, produtivo - industrial, agrícola -, tecnologia e terra);

2. A classe dos inovadores: cientistas, engenheiros, técnicos, consultores contratados pelo capital para promover um contínuo processo de inovação tecnológica e administrativa interno às empresas. $O$ rendimento de um agente inovador não é, a rigor, salário, mas renda do saber. A atividade inovadora não produz mercadorias, mas funciona como promotora do aperfeiçoamento do processo produtivo. Os inovadores correspondem às forças criativas;

3. Os trabalhadores qualificados: dos diversos setores agrícolas, industriais e do terciário. Mantêm seus postos de trabalho com ganhos razoáveis. Personificam as forças produtivas;

4. Os desclassificados ou desfiliados: a grande multidão que oscila entre o desemprego crônico e os pequenos "bicos". O não rendimento dessa categoria, ou seja, seu rendimento oriundo da criminalidade, da mendicância, da pequena extorsão, da chantagem familiar, de favores do Estado etc., é também uma consequência imediata das relações de produção - tanto quanto o salário - e se generaliza assim que o salário de mercado atinge um patamar inferior ao mínimo necessário para a reprodução material do indivíduo. Os desclassificados sinalizam com carências, privações e, por outro lado, com necessidades que, se não satisfeitas, poderão conformar o que Agnes Heller (1972) denomina de "necessidades radicais"36.

Bauman (1999) assevera que, na modernidade líquida, fluida, liquefeita, em que tudo flui, é justamente a velocidade de movimento, em escala local e global, que se tornou o fator crucial de estratificação social; o elemento determinante na hierarquia de dominação:

No mundo do pós-guerra espacial, a mobilidade tornou-se o fator de estratificação mais poderoso e mais cobiçado, a matéria de que são feitas e refeitas diariamente as novas hierarquias sociais, políticas, econômicas e culturais em escala cada vez mais mundial [...]. A mobilidade adquirida por "pessoas que investem" - aquelas com capital, com dinheiro necessário para investir - significa uma nova desconexão do poder face a obrigações, com efeito uma desconexão sem precedentes na sua radical incondicionalidade: obrigações com os empregados, mas também com os jovens e fracos, com as gerações futuras e com a autorreprodução das condições gerais de vida; em suma, liberdade face ao dever de contribuir para a vida cotidiana e a perpetuação da comunidade. (1999, p. 15)

\footnotetext{
${ }^{36}$ São radicais as necessidades que não podem ser satisfeitas e, mesmo que satisfeitas para uma parte da sociedade, a satisfação não pode ser generalizada. Com as necessidades radicais a vida cotidiana se torna insuportável, intolerável. As necessidades radicais se propõem como necessidades e como consciência das necessidades, como fatores de transformação (PRADO, 2001). Os desclassificados, por nada possuírem, têm, dialeticamente, liberdade para transformar.
} 
As elites do capitalismo pós-industrial e globalizado são flexíveis e apresentam ampla liberdade de movimento. Lucram em diversos espaços e, na menor sinalização de prejuízos, revogam os frágeis compromissos assumidos com a localidade e migram, deixando, muitas vezes, no rastro de seus movimentos, um desolador quadro social de miserabilidade.

No outro polo da hierarquia, a ausência de movimento caracteriza as camadas subalternizadas, enraizadas na localidade, petrificadas em destinos funcionais ou disfuncionais e impotentes frente aos movimentos despóticos do capital. Nos estratos inferiores predomina a "redundância estrutural", os inimpregáveis, economicamente inúteis e socialmente descartáveis. No parecer de Bauman:

\begin{abstract}
As pessoas que ficam fora do jogo também são deixadas sem uma função que possa ser vista como "útil", muito menos indispensável, para o suave e lucrativo funcionamento da economia. Não são necessários como os supostos produtores; mas numa sociedade em que os consumidores, e não os produtores, são considerados a força propulsora da prosperidade econômica (esperamos que a recuperação "guiada pelo consumidor" nos tire dos problemas econômicos), os pobres também são inúteis como consumidores: não serão seduzidos por lisonjas do mercado, não possuem cartão de crédito, não podem contar com o cheque especial nos bancos e as mercadorias que mais precisam trazem pouco ou nenhum lucro para os comerciantes. Não é de admirar que eles estejam sendo reclassificados como "subclasse": não mais uma anormalidade temporária esperando ser retificada e posta outra vez na linha, mas uma classe fora das classes, uma categoria colocada permanentemente fora dos limites do "sistema social", uma categoria a que o resto de nós prefere não pertencer. $E$ todos estariam mais confortáveis se ela não existisse. (2008b, p. 100)
\end{abstract}

\title{
11. CONCLUSÃO
}

A análise empreendida, trilhando as sendas da Sociologia, procedeu à retomada de aspectos do fordismo e toyotismo como ferramenta metodológica para abordagem da vinculação entre organização do processo produtivo e vulnerabilidade crescente dos segmentos trabalhadores, bem como com a reconfiguração das classes sociais.

$\mathrm{Na}$ literatura pesquisada, o fordismo/taylorismo foi caracterizado pela rigidez dos processos, pela separação hierárquica entre as atividades de concepção/administração e a de execução, pela concentração dos operários em vastas unidades fabris, com produção em larga escala para consumo de massa e, na esfera externa aos muros das organizações, pela vinculação com o aparato estatal intervencionista e regulador das relações entre capital e trabalho (Estado de Bem-Estar Social). Constituiu-se uma organização social e produtiva centralizada no trabalho como produtor de valor.

O período de vinculação entre fordismo e keynesianismo, de pujança produtiva e geração de riquezas, engendrou as futuras mudanças. Possibilitou condições que favoreceram o capitalismo no enfrentamento às adversidades, como a crise do petróleo de 1973 e a limitação produtiva imposta às grandes corporações. Nesse contexto, outro modelo de organização produtiva e social, o toyotismo, foi promovido e constituiu um dos pilares da denominada "sociedade pós-industrial". O toyotismo caracteriza-se pela flexibilidade, pela adoção de tecnologias poupadoras de mão de obra, pela economia de recursos, pela produção em pequenos lotes e demandados pelo consumo, pela mobilidade de informações, produtos e pessoas, pela globalização das finanças e do mercado e pela hegemonia do neoliberalismo enquanto ideário defensor do Estado mínimo: pregando a desconstrução do Estado de Bem-Estar Social em 
prol da liberalização do mercado e da destituição dos direitos sociais, entendidos, estes, como gastos inadmissíveis.

A centralidade do trabalho foi fragilizada, e os múltiplos setores laborais conheceram um processo de precarização e vulnerabilidade, com redução dos salários; reencetamento de formas de trabalho não formalizado - doméstico, subterrâneo, parcial, hifenizado, terceirizado; desmonte do aparato legal e estatal de proteção social; flexibilização; mobilidade; desestabilização dos estáveis; exportação de unidades fabris para áreas de reduzidas exigências de proteção ambiental e laboral; enfraquecimento dos sindicatos enquanto entidades mobilizadoras e representativas dos trabalhadores.

Segmentos expressivos foram lançados em um estado de inimpregabilidade, conformando um conjunto de descartados do processo produtivo. Segmentos que descortinaram a complexidade da estruturação social, conformando elementos de uma ampla discussão em torno de uma nova teoria das classes sociais, além da polarização entre burguesia e proletariado. Tornando mais elevada essa complexidade, não se pode descurar do papel desempenhado pelos inovadores, pelos detentores do saber científico aplicado à produção. A ciência foi reduzida a instrumento produtivo.

Em suma, a mobilização da bibliografia demonstrou que ocorreram mudanças na dinâmica da relação entre capital e trabalho, que elas afetaram a classe que vive do trabalho e promoveram uma reconfiguração social.

\section{REFERÊNCIAS BIBLIOGRÁFICAS}

ANTUNES, Ricardo. Trabalho, reestruturação produtiva e algumas repercussões no sindicalismo brasileiro. In: ANTUNES, Ricardo. Neoliberalismo, trabalho e sindicatos: reestruturação produtiva na Inglaterra e no Brasil. São Paulo: Boitempo, 1997.

ARAÚJO, Ângela Maria Carneiro de. Globalização e trabalho: uma resenha da literatura. BIB, São Paulo, n. 52, p. 5-44, $2^{\circ}$ seme. 2001.

BAUMAN, Zygmunt. Amor líquido: sobre a fragilidade dos laços humanos. Rio de Janeiro: Jorge Zahar, 2004.

. Globalização: as consequências humanas. Rio de Janeiro: Jorge Zahar, 1999.

Medo líquido. Rio de Janeiro: Jorge Zahar, 2008a.

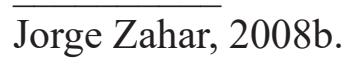

A sociedade individualizada: vidas contadas e histórias vividas. Rio de Janeiro:

BEYNON, Huw. A classe acabou? Reflexões sobre um tema controverso. Dados, Rio de Janeiro, v. 39, n. 2, p. 253-277, 1996.

BOLTANSKI, Luc.; CHIAPELLO, Ève. O novo espírito do capitalismo. São Paulo: WMF/ Martins Fontes, 2009.

CASTEL, Robert. As metamorfoses da questão social: uma crônica do salário. Petrópolis: Vozes, 1998.

CAVALCANTE, Sávio; WOLFF, Simone. Incentivos vazios. Sociologia: Ciência \& Vida. São Paulo, ano II, n. 13, 2007.

CHESNAIS, François. A mundialização do capital. São Paulo: Xamã, 1996. 
DAWSEY, John Cowart. Cultura proletária: um estudo socioantropológico. Piracicaba: Unimep, 1990.

DRUCK, Maria da Graça. Terceirização: (des)fordizando a fábrica - um estudo do complexo petroquímico. São Paulo/Salvador: Boitempo/Edufa, 1999.

DURKHEIM, Émile. O suicídio. São Paulo: Martins Fontes, [1897] 2000.

GUANAIS, Juliana. Salário por producción y superexplotación del trabajo. In: SILVA, Maria Aparecida de Moraes; VERÇOZA, Lúcio Vasconcelos. (Org.). Vidas tejidas al reverso de la historia: estudios sobre el trabajo en loscañaverales y los campos de flores en Brasil. Ciudad Autónoma de Buenos Aires: CLACSO, 2020. p. 81-109.

Reestruturação produtiva e divisão sexual do trabalho na agroindústria canavieira.

Ideias, Campinas, v. 7, n. 1, p. 111-132, jan./jul. 2016.

GUIMARÃES, Nadya Araújo. Caminhos cruzados: estratégias de empresas e trajetórias de trabalhadores. São Paulo: Editora 34, 2004.

HADDAD, F. Em defesa do socialismo: por ocasião dos 150 anos do Manifesto. Petrópolis: Vozes, 1998.

HARVEY, David. Condição pós-moderna: uma pesquisa sobre as origens da mudança cultural. 12. ed. São Paulo: Loyola, 2003.

. O neoliberalismo: história e implicações. São Paulo: Loyola, 2008.

HELLER, A. O cotidiano e a história. Rio de Janeiro: Paz e Terra, 1972.

HUNT, E. K.; SHERMAN, H. J. História do pensamento econômico. 7. ed. Petrópolis: Vozes, 1988.

LEFEBVRE, Henri. O direito à cidade. São Paulo: Moraes, 1991.

LIMA, Jacob Carlos. As artimanhas da flexibilização: o trabalho terceirizado em cooperativas de produção. São Paulo: Terceira Margem, 2002.

MASI, Domenico de. Sociedade pós-industrial. São Paulo: Senac, 2000.

MARX, Karl.; ENGELS, Friedrich. O manifesto do Partido Comunista. São Paulo: Boitempo, 1998.

MARX, Karl. O capital. São Paulo: Nova Cultural, 1996. (Livro Primeiro).

MEULDERS, Daniele. A flexibilidade na Europa. In: HIRATA, Helena; MARUANI, Margareth. (Org.). As novas fronteiras da desigualdade: homens e mulheres no mercado de trabalho. São Paulo: Senac, 2003. p. 273-285.

OFFE, Claus. Trabalho e sociedade: problemas estruturais e perspectivas para o futuro da "sociedade do trabalho". Tradução de Gustavo Bayer E. Margrit Martincic. Rio de Janeiro: Tempo Brasileiro, 1989.

POCHMANN, Márcio. Reestruturação produtiva: perspectivas de desenvolvimento local com inclusão social. Petrópolis: Vozes, 2004.

PRADO, Ediano Dionisio do. "Vila Ilze": o viver fragmentado do "boia-fria": um estudo sobre o cotidiano dos trabalhadores volantes de Itapira. Dissertação. (Mestrado em Sociologia) Universidade Estadual de Campinas, Campinas, 2001. 
RAGO, Luiza M.; MOREIRA, Eduardo, F. P. O que é taylorismo. São Paulo: Brasiliense, 1993.

RAMALHO, José Ricardo. Precarização do trabalho e impasses da organização coletiva no Brasil. In:ANTUNES, Ricardo. (Org.). Neoliberalismo, trabalho e sindicatos: reestruturação produtiva na Inglaterra e no Brasil. São Paulo: Boitempo, 1997.

SADER, Emir. Cartas a Che Guevara: o mundo trinta anos depois. São Paulo: Paz e Terra, 1997.

SANTOS, Milton. Metamorfoses do espaço habitado. 4. ed. São Paulo: Hucitec, 1996.

SILVA, Maria Aparecida de Moraes. Cortadores de cana e os (não) direitos. Travessia. São Paulo, CEM. Maio-Agosto, p. 26-36, 2008.

. Errantes do fim do século. São Paulo: Unesp, 1999.

- A morte ronda os canaviais paulistas. Revista da Associação Brasileira de Reforma Agrária, v. 33, n. 2, p. 111- 142, 2006.

SOUZA, Jessé et al. Ralé brasileira: quem é e como vive. Belo Horizonte: Editora da UFMG, 2009.

VERÇOZA, Vasconcellos, L. Os saltos do canguru nos canaviais alagoanos: um estudo sobre trabalho e saúde. Tese. (Doutorado em Sociologia) - Universidade Federal de São Carlos, São Carlos, 2016.

WALBY, Sylvia. As figuras emblemáticas do emprego flexível. In: HIRATA, Helena; MARUANI, Margareth. (Org.). As novas fronteiras da desigualdade: homens e mulheres no mercado de trabalho. São Paulo: Senac, 2003.

WEBER, Max. Economia e sociedade. Brasília: Editora da UNB, 1999.

Os três tipos puros de dominação legítima. In: COHN, Gabriel. Sociologia de Max Weber. São Paulo: Ática, 1979.

WOOD, Stephen. Toyotismo e/ou japonização. In: HIRATA, Helena S. (Org.). Sobre o "modelo" japonês: automatização, novas formas de organização e relações de trabalho. São Paulo: Editora da USP, 1993. 